\title{
Subsurface Structural Analysis Using Well Logs to Study Faults of the Lower Atokan Formation in the Arkoma Basin, Northcentral Arkansas
}

\author{
Fatimah Al_Asadi ${ }^{1}$, Wathiq Abdulnaby ${ }^{2}$, Doy Zachry ${ }^{3}$ \\ ${ }^{1}$ (Geoscience Department, Fulbright Collage/ University of Arkansas, USA) \\ ${ }^{2}$ (Department of Geology, College of Science/ University of Basra, Iraq) \\ ${ }_{3}^{3}$ (Geoscience Department, Fulbright Collage/ University of Arkansas, USA)
}

\begin{abstract}
Well logs observations have contributed to our understanding of the subsurface structures of the Arkoma Basin. These observations have led to a new explanation of the relationship between surface and subsurface structure of the basin. About 1500 well logs were used in this study to conduct a subsurface structural analysis of faults in the Arkoma basin of northcentral Arkansas. The Arkoma Basin is one of many petroleum basins in the United States which is structurally characterized by series of normal faults. In this study the faults were analyzed by building a structural contour map for Lower Atokan Formation (about 350 million years in age) and plotting nine cross sections using the well logs. The subsurface contour map shows very good match with the faults in the Arkoma basin. Two master fault zones were recognized in this study; the Mulberry and Clarksville fault zones, with displacement ranges from 1567 feet to 500 feet respectively. These fault zones trend northwest to southeast in the study area with an average strike azimuth of $285^{\circ}$. The principal stress axes that are responsible of forming the faults in the study area were calculated by measuring the attitudes of faults from the subsurface contour map and cross sections. The principal stress axes are represented by the plunge angle and plunge direction. The results show that the directions of the maximum, intermediate, and minimum stress axes of the Mulberry fault are $01^{\circ} / 286^{\circ}, 69^{\circ} / 195^{\circ}, 21^{\circ} / 016^{\circ}$, and of the Clarksville fault are $05^{\circ} / 287^{\circ}$, $66^{\circ} / 186^{\circ}$, and $24^{\circ} / 019^{\circ}$ respectively. From these values, it can be seen that the two master faults are affected by the same tectonic stress regime. This study reveals a new finding of series of subsurface sub-basin structure in the analyzed area. One of the major sub-basins, named the Bullfrog Sub-basin, reveals tremendous extension about 4 miles to the surface and subsurface to the northcentral part of the area.
\end{abstract}

Keywords: Arkoma Basin, Clarksville, Growth Fault, Mulberry, Principle Stress.

\section{Introduction}

In Arkansas, the regional geology consists of three tectonic provinces from north to south; the Ozark Platform, Arkoma Basin, and Ouachita Fold and Thrust Belt. The Arkoma Basin extends from west-central Arkansas to southeastern Oklahoma. The study area lies within the northcentral part of the Arkoma Basin (Figure 1), which is one of many petroleum basins in the United States. The study area is bounded to the north by Township $11 \mathrm{~N}$ and to the south by Township $8 \mathrm{~N}$. The western boundary is Range $23 \mathrm{~W}$ and the eastern boundary is Range $18 \mathrm{~W}$ in Pope and Johnson counties.

The inception of the Arkoma Basin development is recorded in late Mississippian, early Pennsylvanian time. The basin is structurally characterized by series of normal faults. These faults were formed by tectonic activities that were associated with the Ozark Uplift and Ouachita Orogeny. Most of the faults in the Arkoma Basin are normal faults with east-west trending down to the south.

Two master faults were recognized in the study are; the Mulberry and Clarksville faults. The Mulberry Fault bounds the northern side of the Arkoma Foreland Basin and serves as the transitional boundary of the Arkoma Basin with the Ozark Platform. The Clarksville fault is mapped south of the Mulberry Fault, north of the Arkansas River. The two faults are dipping to the southeast of the study area. The project is applied to an area of about 1080 square miles. 




Fig. 1: Tectonic divisions of Arkansas according to the USGS. The blue rectangle represents the study area, located at the northern boundary of the Arkoma Basin to the south of the Ozark Plateau.

The primary objective of subsurface structural analysis of the study area is to develop an understanding of the overall structural behavior of rock deformation. Explaining the structural classification of the main features of the study area includes the geometrical and genetic analyses. These include determining the attitudes of faults and the affective stresses that caused the basin.

Analyzing raster well logs is the primary method that was used to accomplish this study in order to provide a better understanding of the structural geology of the study area. The well logs are were used to generate two east-west and seven north-south structural cross sections as well as building the structural contour map. Within the study area, 1549 wells were processed using the Information Handling Services (IHS) Petra log software (Figure 2). The well logs were correlated using gamma ray and resistivity curves to pick the formations tops based on an identical well log signature in a type log, provided by the Fort Smith Geological Society (FSGS), within the study area (Figure 3). The wells within the study area were selected based on location, drilling depth, and the quality of the log curves. Units were identified by examining boundaries on the well logs, and include the Hale, Bloyd (Kessler and Brentwood members), Lower Atokan (the base of the Casey unit), and Middle Atokan (Tackett) formations (Figure 4).

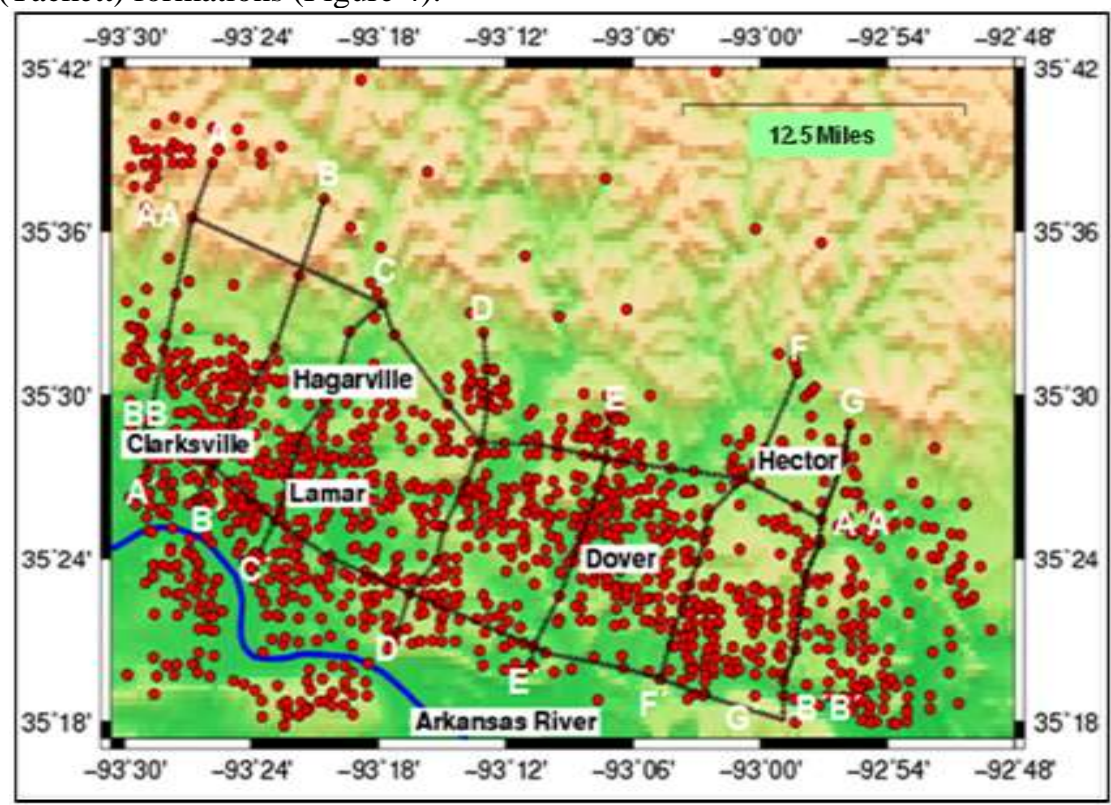

Fig. 2: The distribution of gas wells in the study area of the Arkoma Basin, with nine cross sections to fully cover the overall subsurface structure and reduce the margin of error with mapping the faults. Most of the wells south of the Arkansas River are identified to be deviated wells, which are not included in this study. 


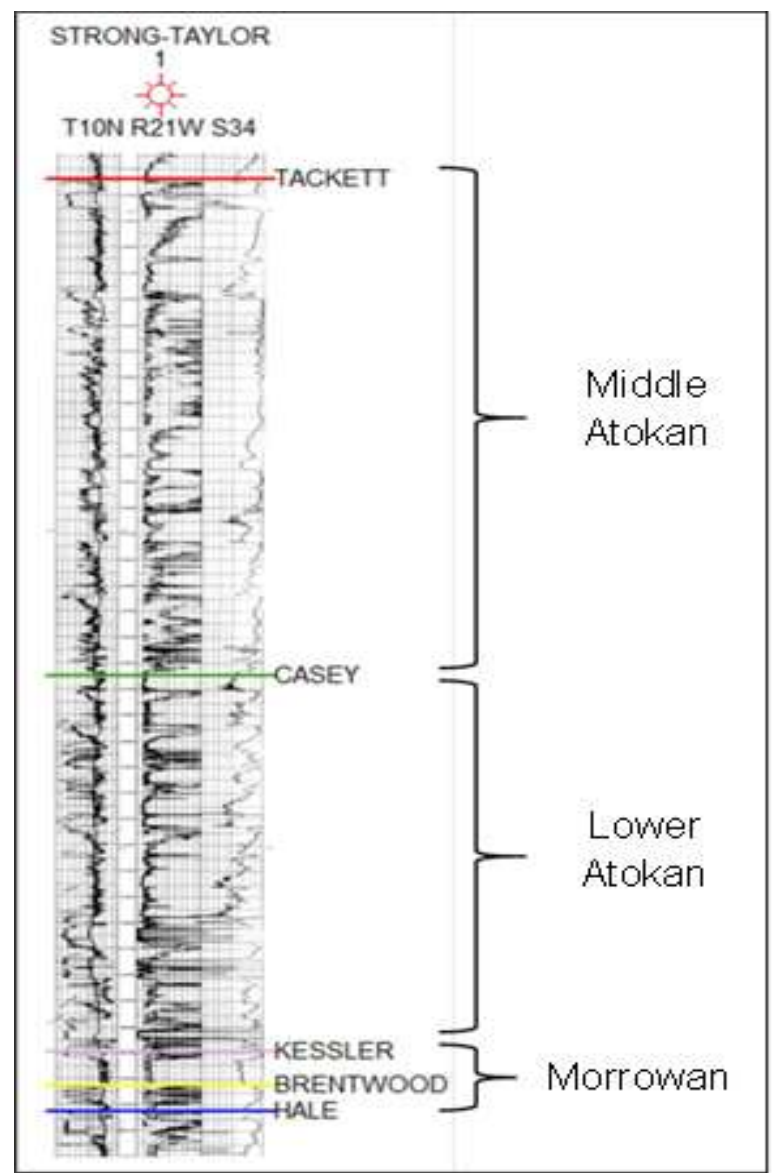

Fig. 3: Wire-line type log showing the log signature for all of formations in the study area highlighted with distinctive colors.

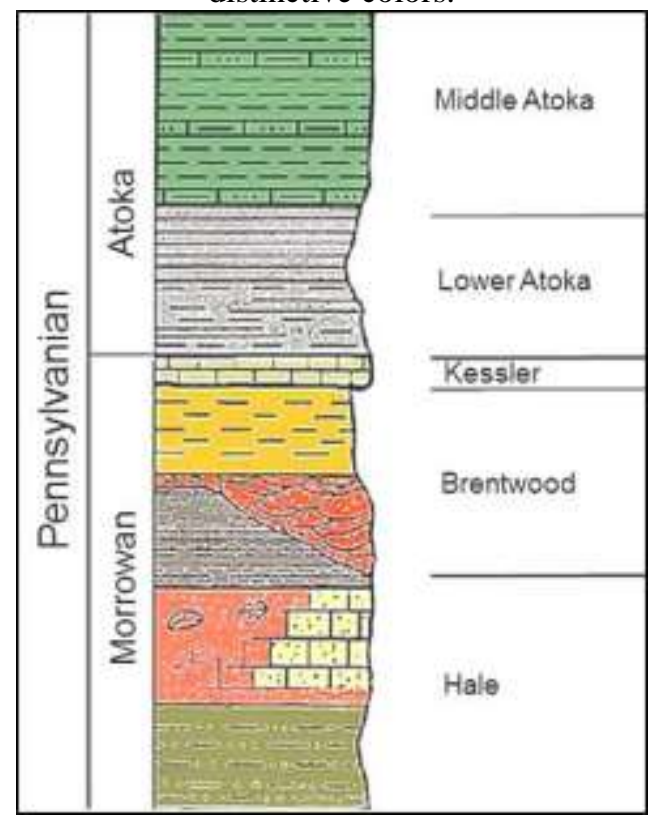

Fig. 4: Generalized stratigraphic column of the Morrowan and Atokan series of the Pennsylvanian succession of northcentral Arkansas (Modified from McGilvery, 1982).

\section{Geological Setting}

The study area strata exhibit southerly dips which range from less than $1^{\circ}$ on the Ozark Plateau to $8^{\circ}$ on the northern flank of the Arkoma Basin. The northern part of the Arkoma Basin is dominated by numerous northwest to southeast trending faults and asymmetrical folds. During the Pennsylvanian, clastic sediments filled the basin forming the Hale and Atokan formations, while carbonate sediments covered the upper part of the 
Morrowan series, specifically in the Kessler and Brentwood members of the Bloyd Formation (McGilvery, 1982). The sediments that filled the Arkoma Basin were derived from the southern margin of the North American Craton.

Sediments were deposited in thicknesses up to 25,000 feet $(5.5 \mathrm{~km})$ simultaneously with the fault driven subsidence in the basin (Houseknecht, 1986). A complex system of faulting within the Lower to Middle Atokan Formation was described as the inception of the Arkoma Basin development. Most of the faults are normal faults with northwest to southeast strike directions and dip directions to the southwest (Figure 5). In the study area, there are two master faults these are the Mulberry and Clarksville faults, which will be explain more in section 4 .

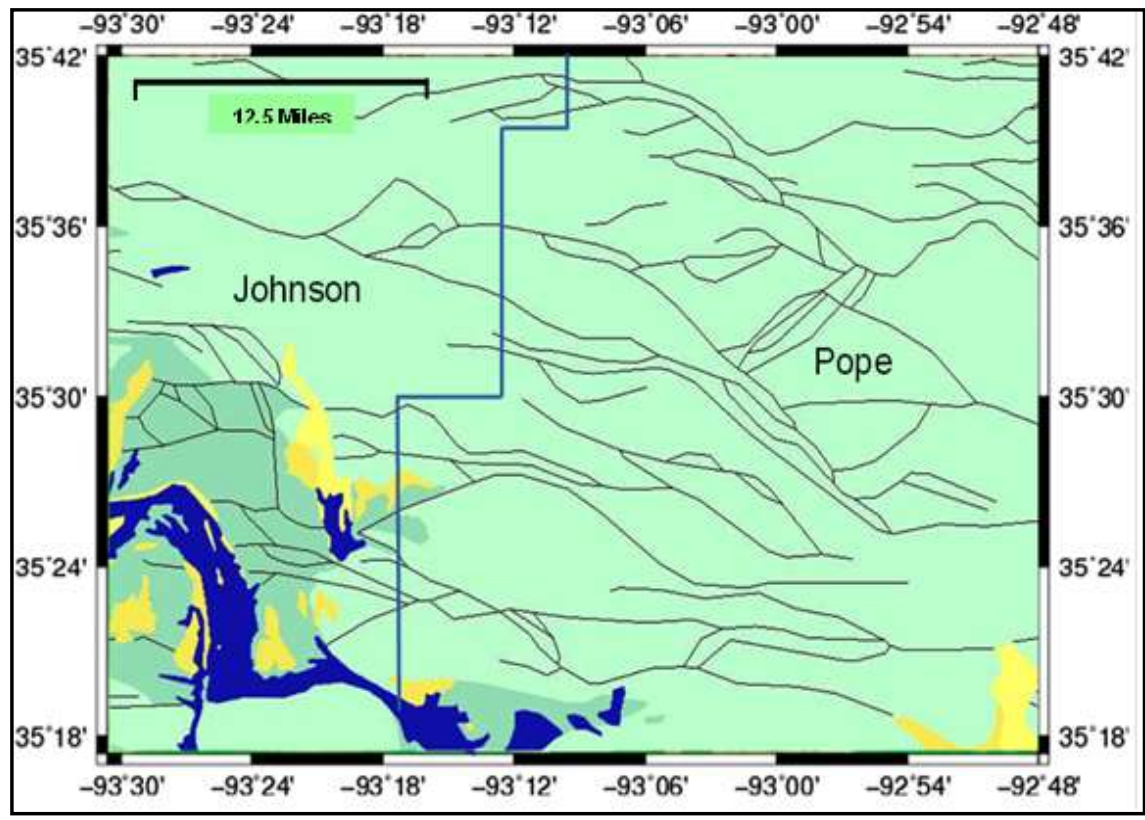

Fig. 5: Structural map of the study area depicting general trending faults. The faults are bifurcated, producing small faults that are generally dipping to the southwest direction. Cretaceous deposits are exposed to the surface of the area in yellow, while Atoka deposits are mapped with light blue (modified from the Arkansas Geological Survey).

Houseknecht and Kacena (1983) and Houseknecht (1986) illustrated the tectonic history of the Arkoma Basin from Late Precambrian to early Paleozoic time, representing the geological time development of the Arkoma Basin. The tectonic series are represented in five stags:

1. The first stage recorded the opening of the Proto-Atlantic Ocean basin during the late Precambrian to Cambrian time.

2. In the Late Cambrian to Early Mississippian time, represented the onset of the ocean basin closure due to the northern encroachment of "Llanoria".

3. By Early Mississippian to Early Atokan time, as a result of southward subduction beneath Llorania, resulting in series of east-west trending normal faults. The basin started to form through the generation of growth faults and an increase in sediment supply from the east side of the basin.

4. During the Early to Middle Atokan time, the ocean closure was completed. The reactivation of the normal growth faults later was causing the development of the foreland basin.

5. Finally, in the Middle to Late Atokan time, the Arkoma Basin development continued to result in complex structural deformation adjacent to the Ouachita Mountains.

During the fourth and fifth tectonic stages, the Middle Atokan Formation experienced major facies thickening, which was controlled mainly by the increase of accommodation space for the received sediments.

\section{Well Log And Contour Map Analysis}

Gamma Ray and resistivity raster logs were used to assist in the general study to the area structure. The well $\operatorname{logs}$ were selected to cover a large portion of the study area. The selected logs were classified to include just the wells with good log signature. The other well logs were neglected, such as deviated wells and logs with bad signature.

Since most of the structural features of the Arkoma Basin are well defined at the Lower Atokan Formation in most of the wells, the Lower Atokan contour map was selected to represent the overall structure of 
the basin. The structural contour maps were constructed by using the logs data of the formations tops. The resulted contour map reflects primary structural features. It shows the trace of the two master faults to the north and south portion of the study area that was separated into three subsurface regions. Strata of the up-thrown block of the master faults are thinner comparing to the down-throw block. The structural contour map on the Lower Atokan Formation illustrates very good match between the subsurface contour lines and the Quaternary faults that were proposed by the USGS (Figure 6). More details on this figure will be mentioned later.

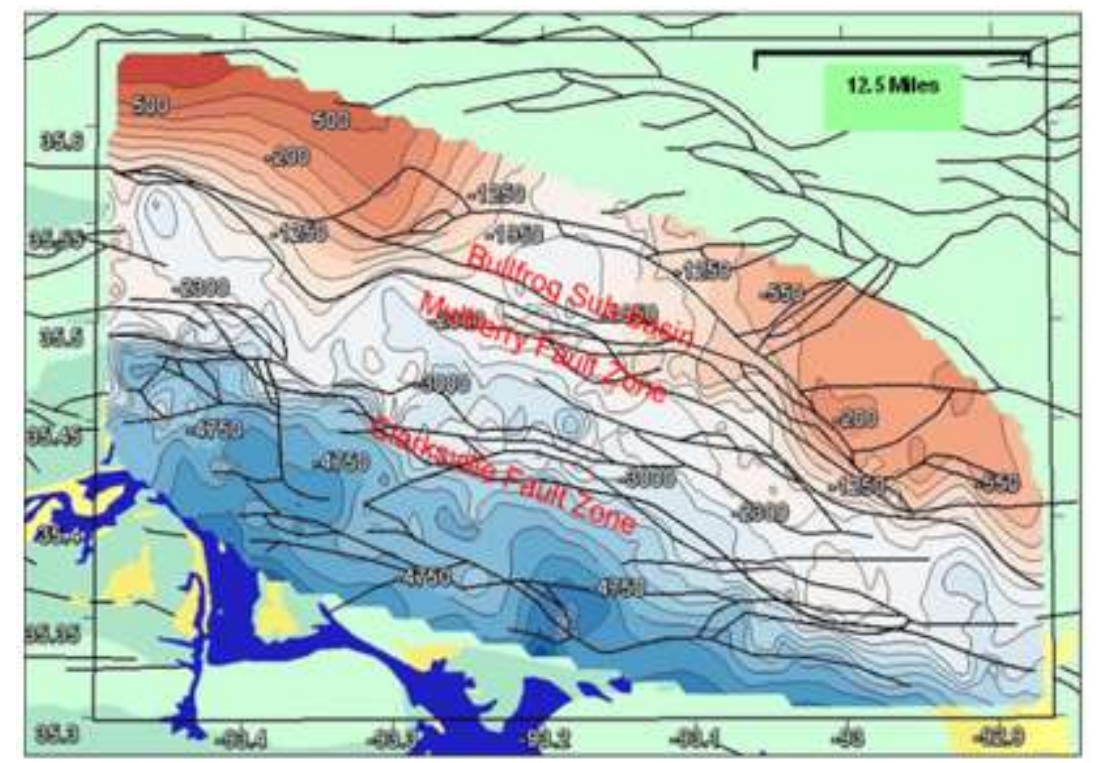

Fig. 6: Structural contour map of the Lower Atokan Formation plotted from well logs data. The Mulberry Fault, Clarksville Fault, and Bullfrog sub-basin are the main structural features in the study area.

Furthermore, the well logs were used to produce nine structural cross sections. Only four structural cross sections were presented in this study (See figure 2). Two north-south cross sections were chosen to determine the major displacement on the two master faults, and two east-west cross sections to show the lateral changes (Figures 7, 8, 9, and 10). From these sections, most of faults tend to generally trend from northwest to southeast direction. However, other shorter faults have different strike direction which is perpendicular to the major direction of the master faults. The different throws in displacement and relatively huge curvatures on the fault surfaces of the Mulberry fault zone are responsible of forming local sub-basins in the study area. One of these sub-basins is what we called in this study the Bullfrog sub-basin.

Cross section (A-A') is located at the western part of the study area (Figure 7). This cross section extends from the north in Townships 9N-11N, Range 23W in Johnson County. The cross section contains seven well logs. The well logs are spaced relatively close to each other. The wells are spaced at approximately 1 to 3 miles apart. This cross section covers a distance of 13.5 miles. The two master normal faults are mapped in black lines. The thickness of the Lower Atokan Formation is relatively constant through the cross section, while thickness of the Middle Atokan Formation increases toward the southern part of the area. The Middle Atoka shows regional erosion of the upthrown side of the Mulberry Fault, which has a displacement of about 2,170 feet, whereas the Clarksville Fault indicate a smaller displacement compared to the Mulberry Fault of about 1,080 feet. The cross section shows an additional normal fault that has a displacement of about 960 feet. It indicates a semi horst and graben structural features with the last two additional faults. The Mulberry Fault dips in a low angle around $50^{\circ}$ to the southeast. On the other side, the Clarksville Fault is dipping in a high angle of about $83^{\circ}$. The dip angles and displacements of faults were determined based on the analyzed cross sections of the study area. After generating the cross sections in Petra software, each cross section was used to measure the dip angle and displacement of the faults that are placed between two closed spaced distance of the logs. 


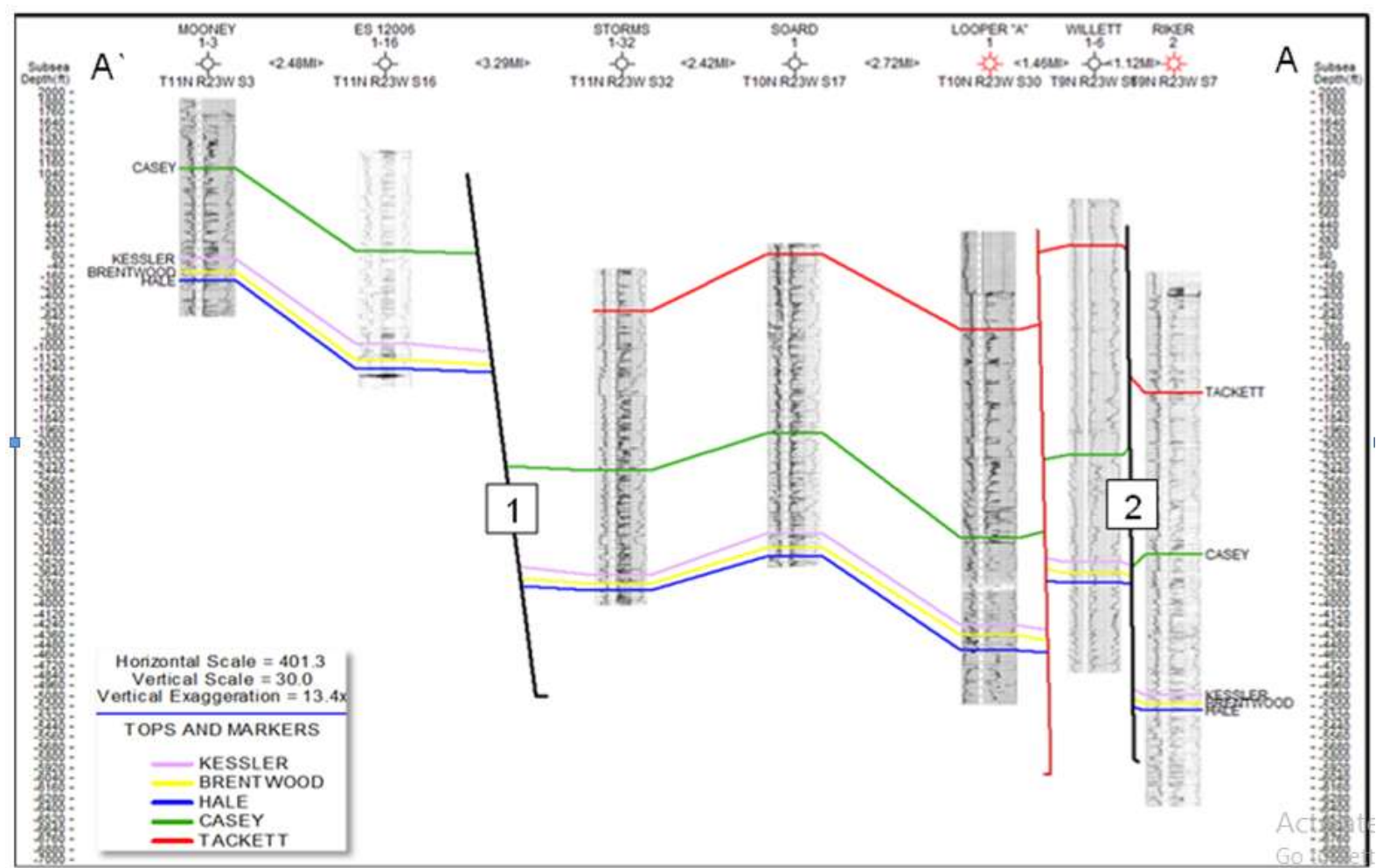

Fig. 7: North to south structural cross section A-A` with the Mulberry (1) and Clarksville (2) faults in the black lines.

Cross section (B-B') (Figure 8) is located at the far western part of the study area. This cross section extends from the north in Townships $10 \mathrm{~N}-8 \mathrm{~N}$, Ranges $18 \mathrm{~W}-19 \mathrm{~W}$ in Pope County. Eight well logs were utilized to construct this cross section. The well logs are chosen to be in a range of between one to two miles, and to cover a total distance of approximately 13 miles from north to south. The cross section is interpreted to have four normal faults that originated in a step faulting style. The displacement on the two master faults is measured to reveal a value of 1,530 feet of the Mulberry and 1,400 feet of the Clarksville.

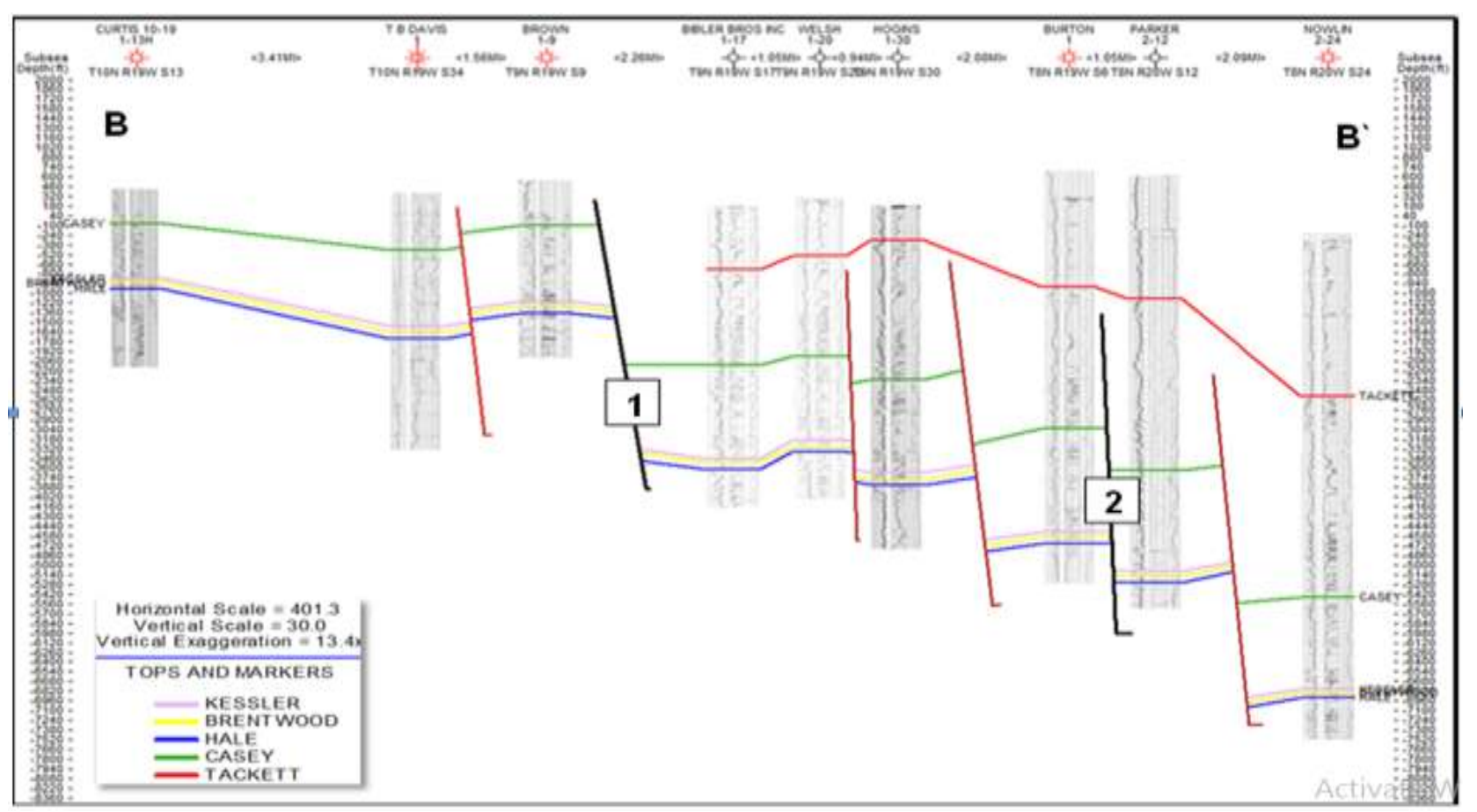

Fig. 8: North to south structural cross section B'-B with the Mulberry (1) and Clarksville (2) faults in the black lines. The Thickness of the Middle Atokan Formation increases to the south part of the study area. 
Cross section (AA-A 'A`) is located in in both Johnson and Pope counties through Townships $11 \mathrm{~N}-9 \mathrm{~N}$, Ranges $23 \mathrm{~W}-18 \mathrm{~W}$ of the study area (Figure 9). The section contains eleven well logs that span about thirty-two miles from west to east. The primary reason to construct this cross section is to show the orientation of the subbasin that is perpendicular to the Mulberry Fault. The well logs are equally spaced in distance to show the overall structural configuration of the northern part of the area. The cross section shows a structural feature described as the Bullfrog sub-basin between well Brown and (1-9) and well Watson (1), with a vertical displacement range from 1,800 feet to 1,650 feet to the east. The cross section shows a pattern of step faulting. The normal faults that bounded the sub-basin are varying in dips. The western side of the fault dips at a low angle of $48^{\circ}$, while the eastern side dips at a high angle of $77^{\circ}$, forming asymmetrical sub-basin.

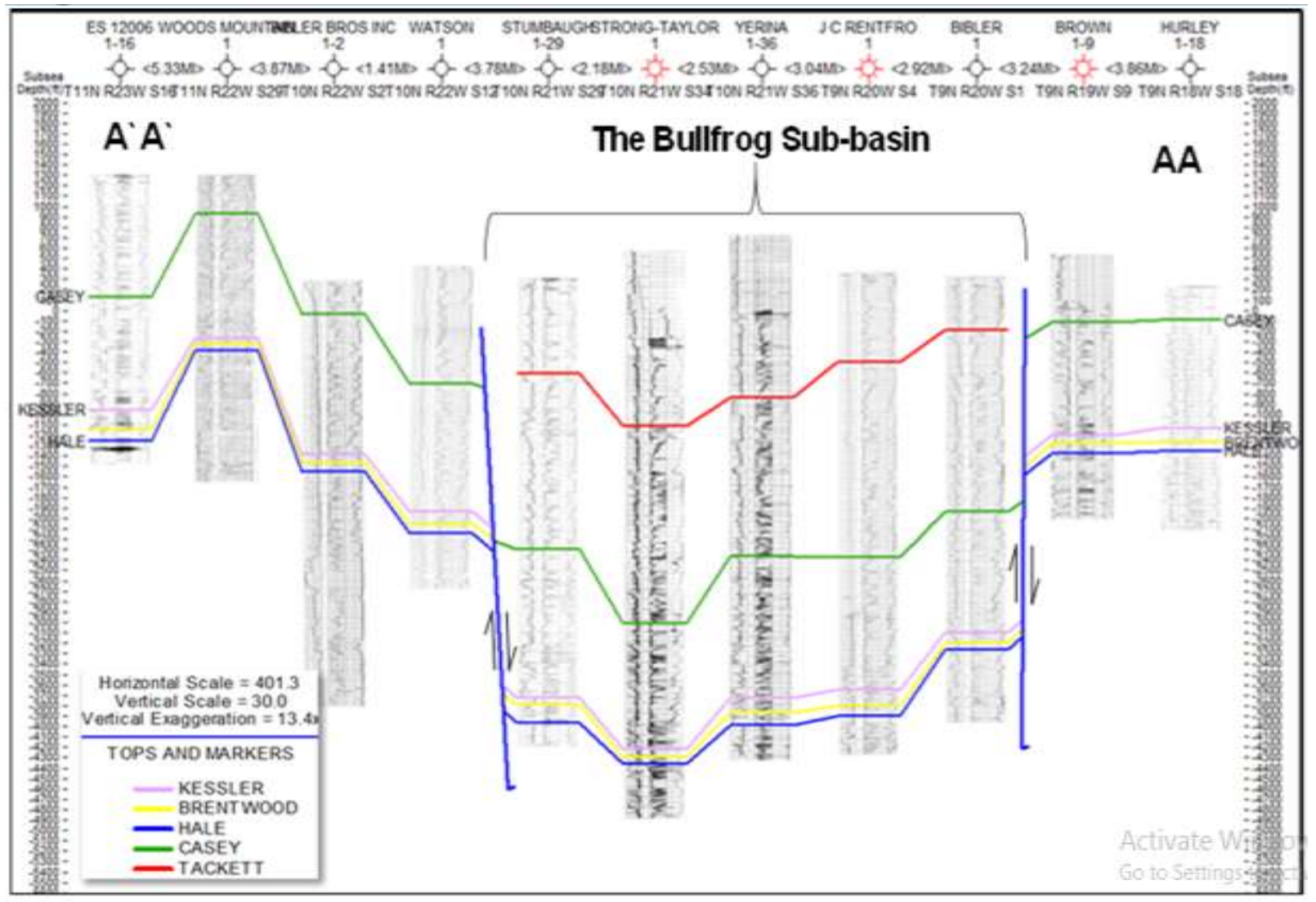

Fig. 9: West to east structural cross section AA-A`A` with the bounding faults of the Bullfrog subbasin mapped in blue lines. The Lower Atokan Formation eroded to the sides of the Bullfrog sub-basin and presented completely inside the sub-basin.

Cross section (BB-B`B`) is located in both Johnson and Pope Counties through Townships $9 \mathrm{~N}-8 \mathrm{~N}$, Ranges 22W-20W (Figure 10). The section is constructed by utilizing eleven well logs that span about thirtyone miles from west to east. This cross section is important in terms of measuring the extension of the bounding faults of the sub-basin. The interpretation of the two east-west cross sections supports the idea of that the subbasin might be newer than both the Mulberry and Clarksville faults as they are perpendicular to the Mulberry fault and displace the Middle Atoka Formation. 


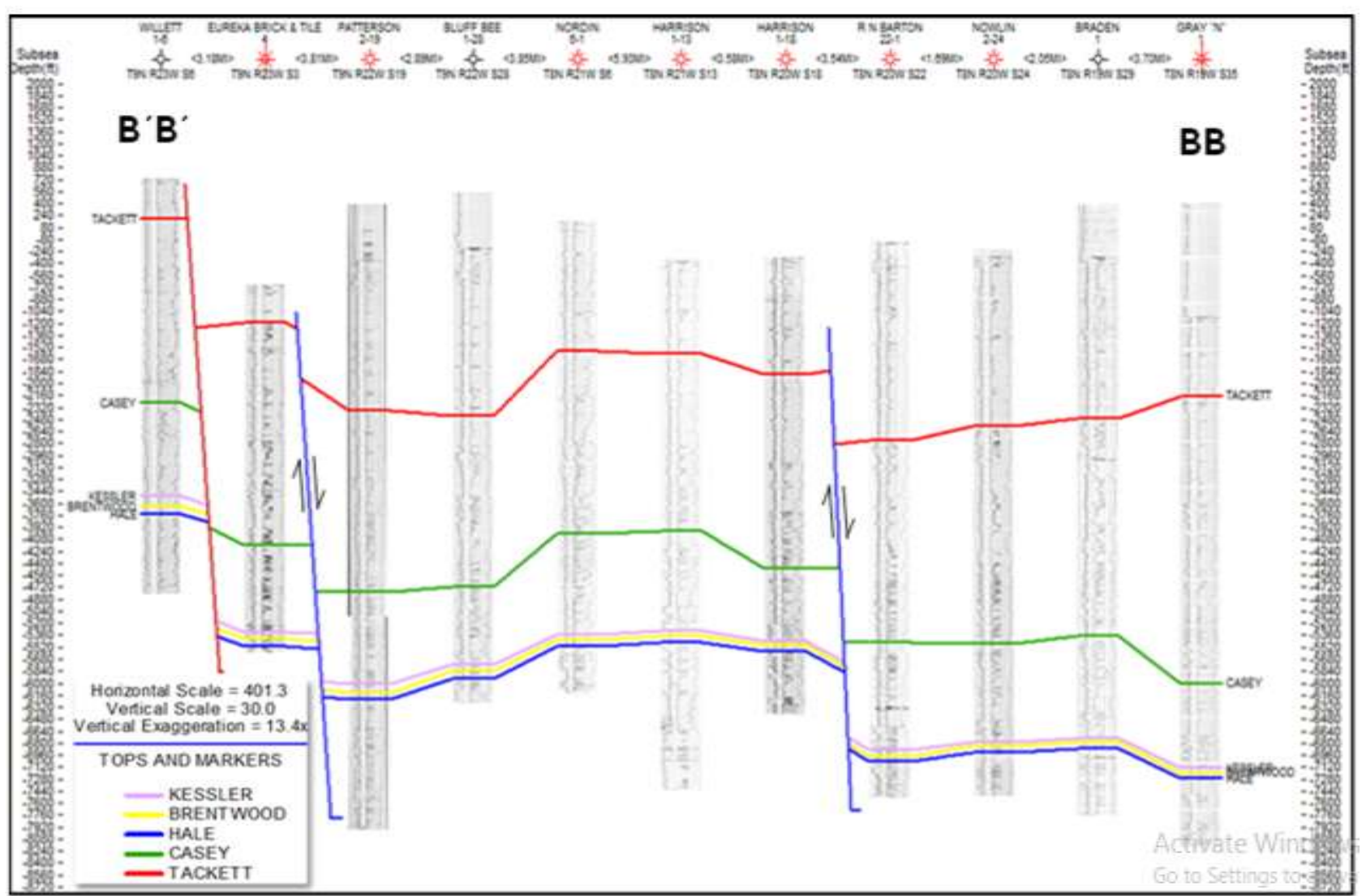

Fig. 10: West to east structural cross section BB-B`B` with the bounding faults of a sub-basin to the southern part of the area. Two faults are mapped in blue lines. These faults follow the same direction of the subbasin bounded faults. They are dipping in the same direction.

\section{Structural Analysis}

Based on the analysis of the structural contour map of the Lower Atokan Formation, well log cross sections, and google earth profiles, the geometrical and genetic structural analyses were established for the Mulberry Fault, Clarksville Fault, and Bullfrog sub-basin. Three google earth elevational profiles are used to aid in providing additional information in terms of correlating the surface structure with the subsurface structural analysis.

\section{a. Mulberry Fault}

The Mulberry Fault is the most northern master northwest-southeast trending normal fault that dips to the southwest. It has been described as a transitional fault between the Ozark Platform and the Arkoma Basin to the southern boundary of the Boston Mountains. In the study area, the Middle Atokan Formation has been eroded on the up-thrown side of the Mulberry fault. The Mulberry Fault crosses the study area in Townships $11 \mathrm{~N}-9 \mathrm{~N}$, Ranges 23W-18W. Two explanations for the development of the Mulberry Fault have been described. First, the Mulberry Fault was interpreted as an extensional normal fault that was reactivated as a result of flexural bending during the convergent of tectonic movement. Also, it has been mentioned that the fault was a product of the reactivation of pre-existing basement faults and then overlaid by sedimentary strata (Long, 2005). According to the measurements of the well cross sections, the average dip of the Mulberry Fault results in a value of about $50^{\circ}$. Additionally, it has a larger vertical displacement of an average of 1567 feet. The elevation profile (Figure 11), taken from google earth, represents north-south cross-sections that is perpendicular to the Mulberry Fault. The profile covers a distance of about 7 miles. The profile shows major vertical displacements on the Mulberry Fault surface. Those profiles indicate that the Mulberry Fault reaches shallow depths to the surface of approximately 1104 feet elevation. 


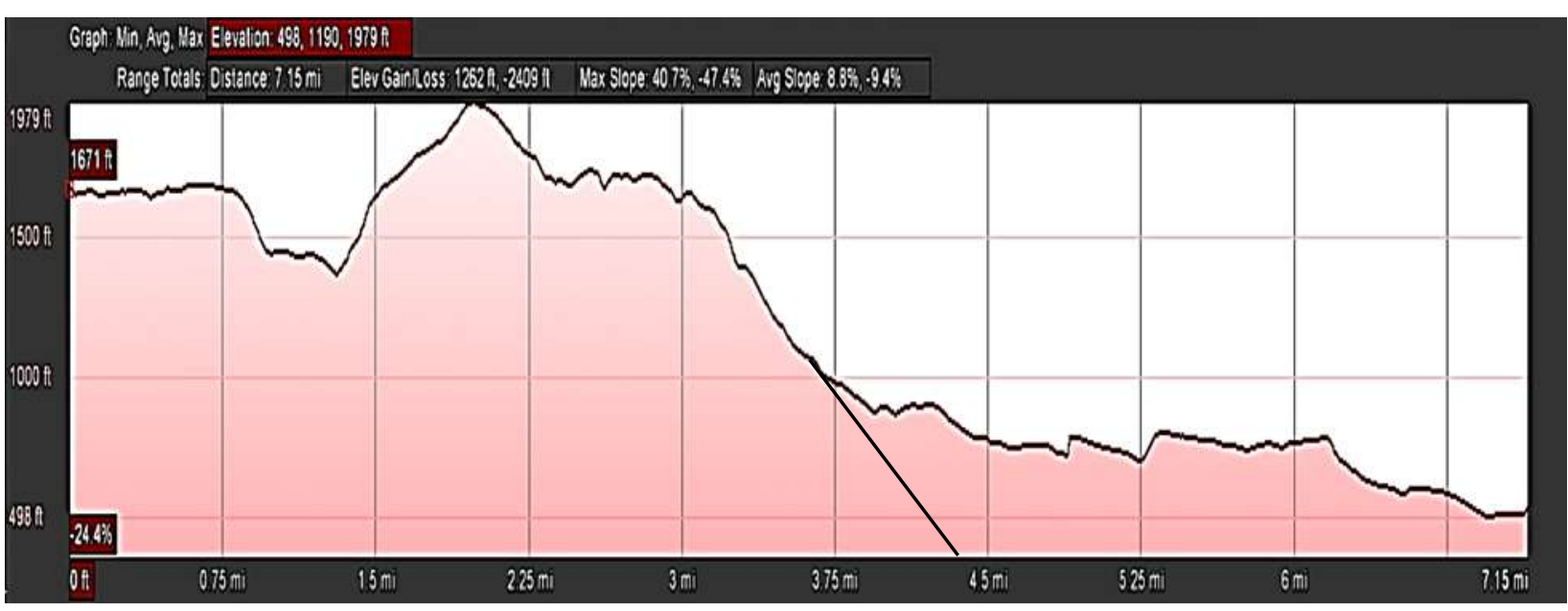

Fig. 11: Google earth elevation profiles showing cross sectional view of the surface topography along the paths for northwest to southeast path of the western part of the Mulberry Fault.

\section{b. Clarksville Fault}

The Clarksville Fault is the second northwest-southeast trending normal master fault that dips of about $70^{\circ}$ to the southwest of the study area, north of the Arkansas River. It extends from Township 10N, Range $23 \mathrm{~W}$ in the western part to Township $8 \mathrm{~N}$, Range $18 \mathrm{~W}$ in the eastern part of the study area for a distance of approximately 31 miles. Very little has been published in terms of the Clarksville Fault characters. It was described for its economic importance of coal production in Arkansas. The Clarksville Fault is interpreted to have a vertical displacement of about 500 feet according to Collier et al. (1907), while in this study it has been measure to have an average vertical displacement of about 1050 feet. Based on the structural analysis of the Clarksville Fault, it seems that this fault was caused by the flexural tectonic movement of the Arkoma Basin.,

Also, the fault might be caused by the reactivation of preexisting normal faults that existed in the basement during early Mississippian, it might have been formed later in early Atokan time. This interpretation is supported by the work of Al-Asadi (2016). According to this work, the fault is a syn-depositional normal fault because of the increase in the depositional thickness of the Middle Atokan Formation, as it is indicated in the structural cross sections to the eastern part of the study area (Figure 12). Additional profiles are made in order to present further evidence for the Clarksville Fault. Also, the Clarksville Fault shows major displacement to the surface that has similar characteristics as the subsurface vertical displacement.

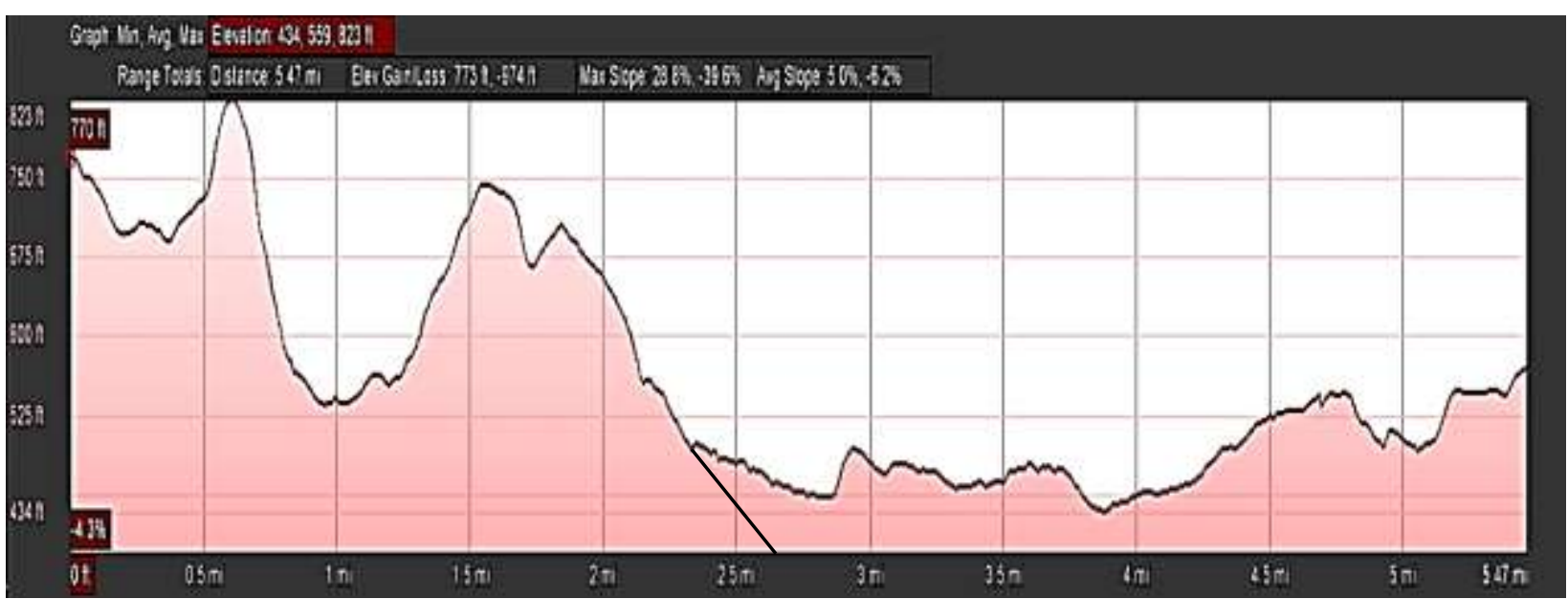

Fig. 12: Google earth elevation profiles showing cross sectional view of the surface topography along the Clarksville Fault.

\section{c. The Bullfrog Sub-basin}

The structural contour map defines a sub-basin, bounded by two north-south trending normal faults. The Bullfrog sub-basin has not been described in previous literature. A 3D diagram is designed based on increasing the vertical exaggeration of the Lower Atokan Formation structural contour map (Figure 13). The Lower Atokan Formation map is considered to be the base map for constructing the Bullfrog sub-basin because 
of the recognizable characterization of the sub-basin comparing to the other formations in the study area. The sub-basin has a measured width of about 16.5 miles in terms of subsurface measurements.

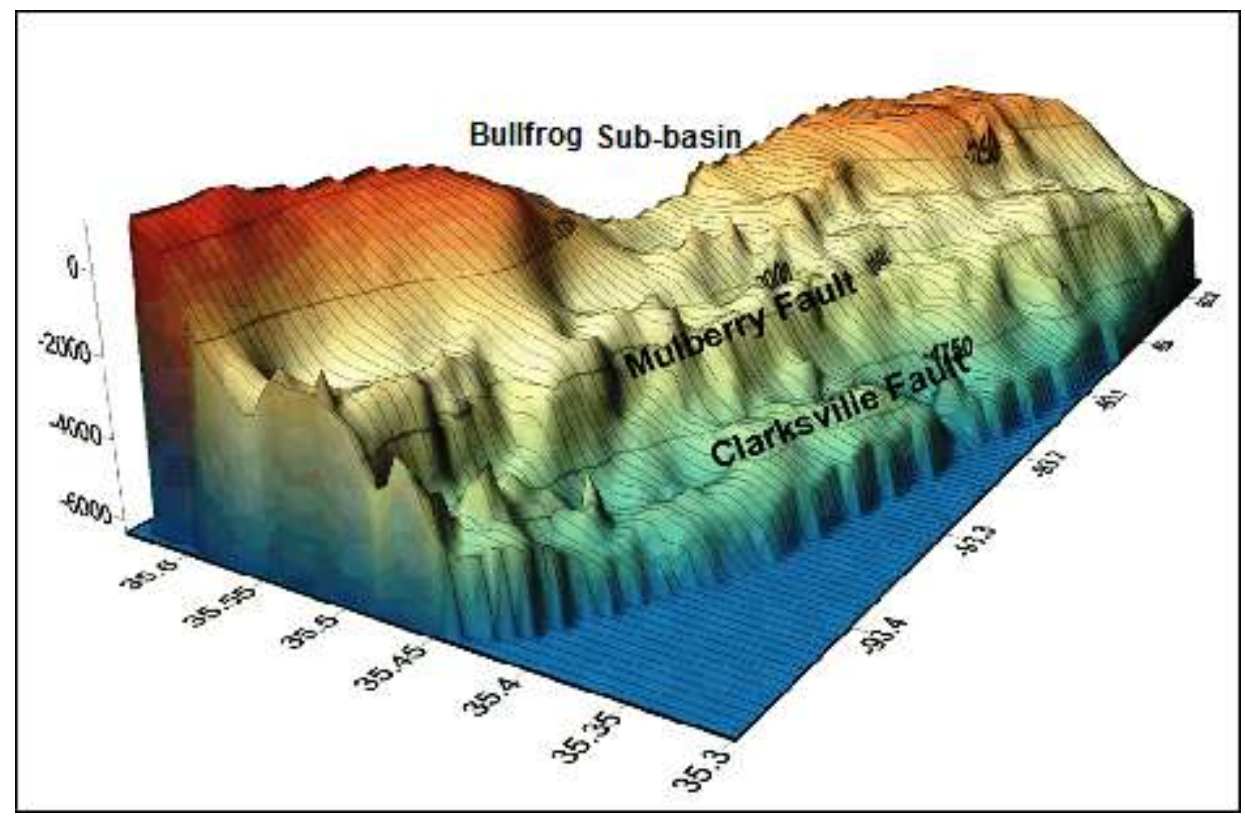

Fig. 13: A three dimensions diagram of the Bullfrog sub-basin defined the Lower Atoka structure contour map.

Additionally, an east-west elevation profile is generated to correlate the surface with subsurface structure of the mapped sub-basin (Figure 14). The profile is mapped to cover a distance of about 10 miles. In correlation with the subsurface cross section (AA-A`A`), the sub-basin shows asymmetrical geometry. Also, obvious evidence presented by the topographic surface of the google earth profile emphasizes the effect of the faults that bound the Bullfrog sub-basin.

Previous publications in the Arkoma Basin interpreted several sub-basins referred to as major synclinal features. Most of these synclines were east-west trending which is the trend of the Bullfrog sub-basin.

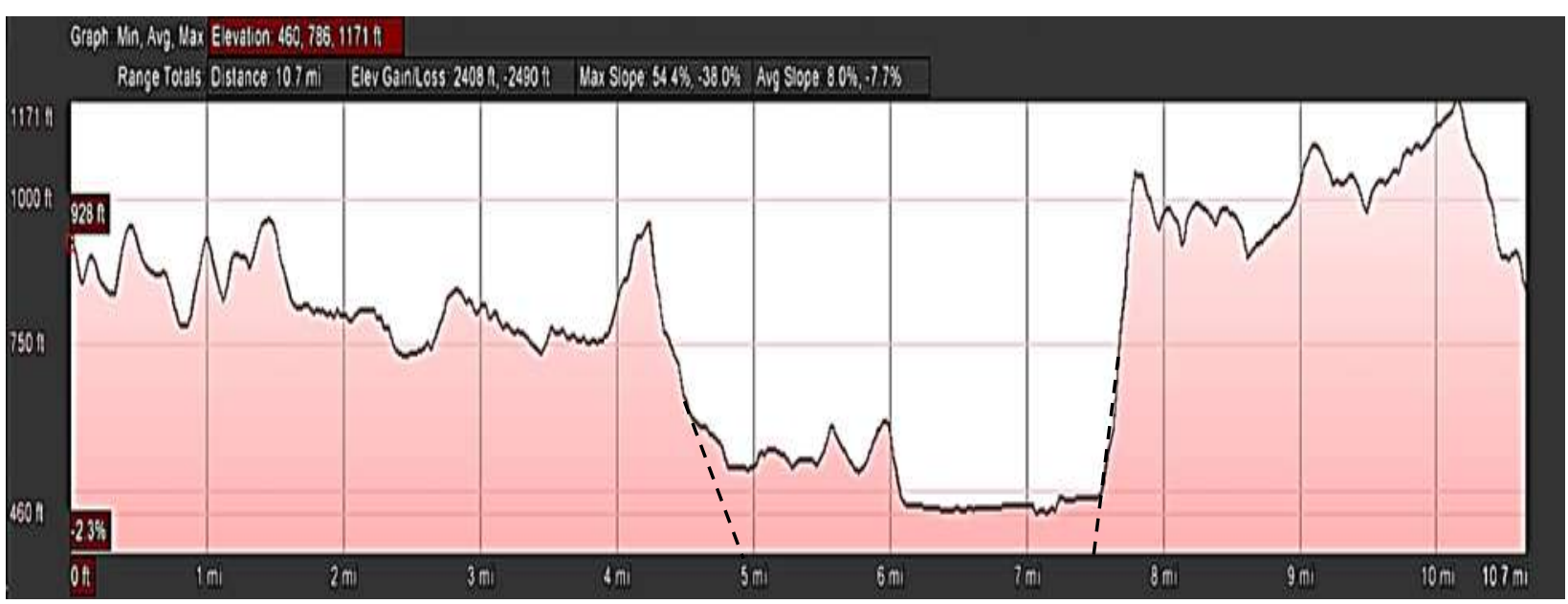

Fig. 14: Google earth elevation profiles showing cross sectional view of the surface topography along east-west direction of the central part of the Bullfrog sub-basin.

\section{Stereographic Projection}

As has been mentioned earlier, the Arkoma Basin developed as a result of series of extensional tectonic movements that caused series of normal faults. An extensional normal fault can be developed as a result of applying vertical or horizontal stresses to rock bodies. Analyzing the principal stress axes is important to study the stress regime in the Arkoma Basin.

The Win-Tensor software was utilized to determine the principle stress axes of faults in the study area. This program is free source program developed originally in DOS by Delvaux (1993) and then modified for 
Windows by Devaux and Sperner (2003). The graphical output of the stress inversion by the Win-Tensor program depicts the projection of the principal stress axes in a lower hemisphere equal-area projection and allows evaluating the overall quality of the result (Delvaux and Barth, 2010).

The stereographic projections that were derived from this software shade more light on the origin and tectonic stress regime of the study area. The data that was derived from measuring the strike directions and dip angles, taken from the cross sections, of the master faults and the two faults that bound the sub-basin were the main input to the Win-Tensor (Table 1). The strike direction of Mulberry and Clarksville faults is approaching $285^{\circ}$ and the dip angle ranges from $50^{\circ}$ to $80^{\circ}$ with an average of $60^{\circ}$ for both faults.

Table 1: Strike directions and dip angles of the Mulberry and Clarksville master faults, and faults bounded the Bullfrog sub-basin, were calculated from the structural contour map and eight cross sections. The strike directions of the faults surfaces were measured by tracing the fault surfaces on the structural contour map, while the dip angles were measured directly from the logs cross sections. Seven of these cross sections are perpendicular to the strike direction of the two master faults and two cross sections are perpendicular to the fault that bounded the Bullfrog sub-basin. All cross sections were utilized as shown in Figure 2.

\begin{tabular}{|c|c|c|c|c|}
\hline Cross-section & $\begin{array}{c}\text { Strike direction of the Mulberry } \\
\text { fault }\end{array}$ & Dip Angle & $\begin{array}{c}\text { Strike direction of } \\
\text { the Clarksville fault }\end{array}$ & Dip Angle \\
\hline $\mathbf{A A}^{\prime}$ & $200^{\circ}$ & $50^{\circ}$ & $198^{\circ}$ & $83^{\circ}$ \\
\hline $\mathbf{B B}^{\prime}$ & $199^{\circ}$ & $54^{\circ}$ & $197^{\circ}$ & $70^{\circ}$ \\
\hline $\mathbf{C C}^{\prime}$ & $200^{\circ}$ & $47^{\circ}$ & $197^{\circ}$ & $67^{\circ}$ \\
\hline DD $^{\prime}$ & $196^{\circ}$ & $82^{\circ}$ & $196^{\circ}$ & $63^{\circ}$ \\
\hline $\mathbf{E E}^{\prime}$ & $195^{\circ}$ & $73^{\circ}$ & $197^{\circ}$ & $55^{\circ}$ \\
\hline $\mathbf{F F}^{\prime}$ & $194^{\circ}$ & $53^{\circ}$ & $197^{\circ}$ & $79^{\circ}$ \\
\hline $\mathbf{G G}^{\prime}$ & $197^{\circ}$ & $61^{\circ}$ & $198^{\circ}$ & $72^{\circ}$ \\
\hline & Sub-basin/West Fault & & Sub-basin/East Fault & $77^{\circ}$ \\
\hline AA-A'A'
\end{tabular}

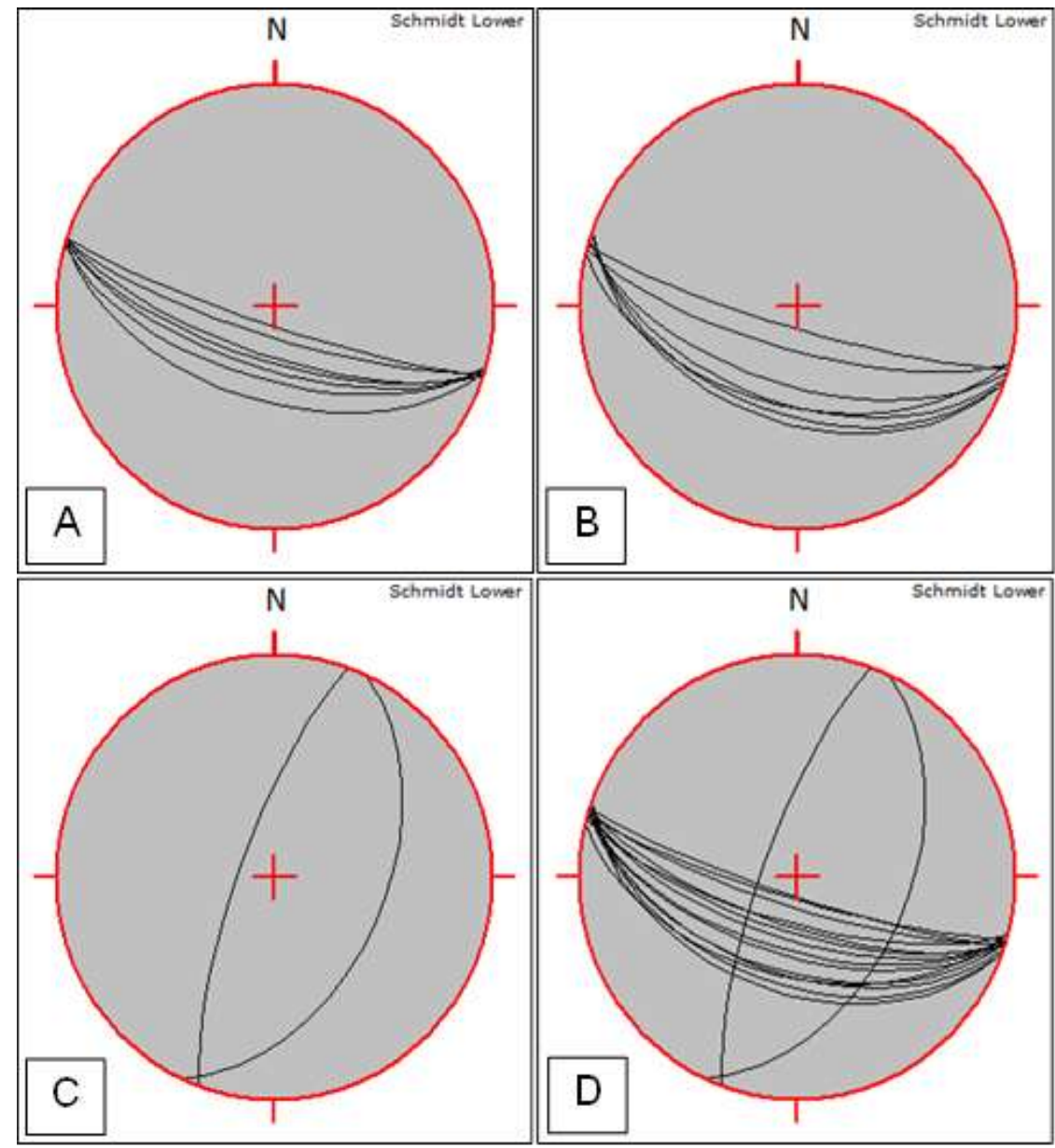

Fig. 15: Equal-area projection of lower hemisphere of the Mulberry Fault (A), the Clarksville Fault (B), the Bullfrog sub-basin (C), and the both master faults and sub-basin to represent the general description of the study area structure (D). 
The direction of the greatest principle stress that is applied to the structural features in the study area was represented in Figure 16. In this figure, the three principal stress axes are represented by a red dot surrounded by a circle for $\sigma 1$, a triangle for $\sigma 2$, and a square for $\sigma 3$. The related horizontal stress axes are represented by large blue arrow outside the stereogram for maximum horizontal stress axis $(\mathrm{SH})$ and red arrow for the minimum horizontal stress axis (Sh). The small circle on the upper left corner of each panel shows the direction and type of the horizontal stress axes. The histograms to the lower left corner of the stereograms depict the distribution of the misfit angle F5 in the Win-Tensor program weighted arithmetically according to the magnitude for each case.

The red arrow (Figure 16) refers to the extensional tectonic movements. The north-south trending faults that bound the Bullfrog sub-basin are interpreted to have the same extensional tectonic regime in the Arkoma Basin.

The Attitude of principal stress axes, which is represented by the plunge angle and plunge direction, of the Mulberry fault are $\sigma 1=01^{\circ} / 286^{\circ}, \sigma 2=69^{\circ} / 195^{\circ}, \sigma 3=21^{\circ} / 016^{\circ}$, and of the Clarksville fault are $\sigma 1=05^{\circ} / 287^{\circ}$, $\sigma 2=66^{\circ} / 186^{\circ}, \sigma 3=24^{\circ} / 019^{\circ}$. From these numbers, it can be seen that the two master faults are affected by the same tectonic stress regime. The Attitude of principal stress axes that are associated with the sub-basin are $\sigma 1=39^{\circ} / 035^{\circ}, \sigma 2=48^{\circ} / 187^{\circ}, \sigma 3=14^{\circ} / 293^{\circ}$. The extensional stress axes that affect the master faults are perpendicular to the extensional stress axes that affect the sub-basin.
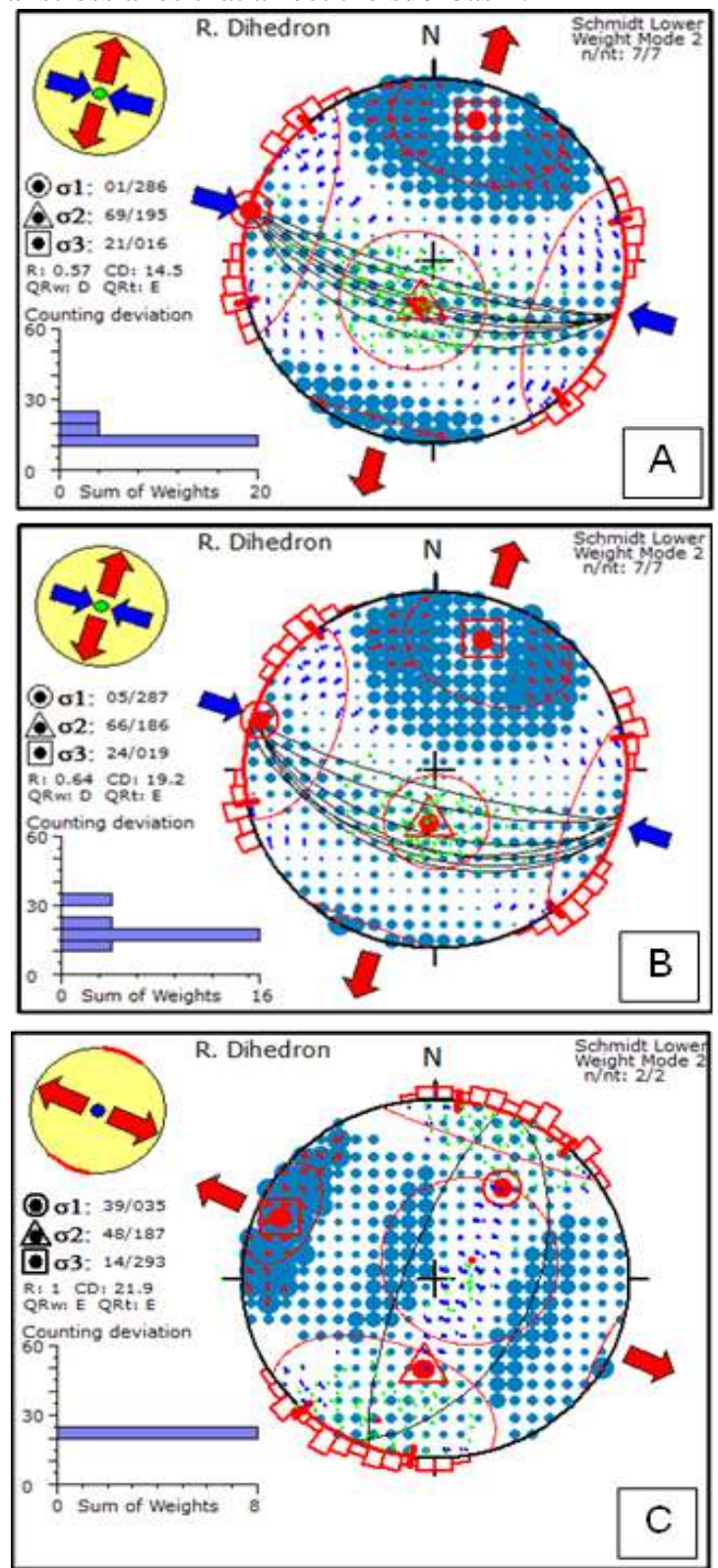

Fig. 16: The principal stress analyses of the Mulberry Fault (A), the Clarksville Fault (B), and the Bullfrog subbasin $(\mathrm{C})$. For more details see the text. 


\section{Discussion and Conclusion}

Evidence from Morrowan and Atokan formations of the northcentral Arkoma Basin suggests that local lithospheric flexural extension presented well by the Bullfrog sub-basin area and its associated master faults. The general observation of the contour map of the Lower Atokan Formation, with two structural cross sections, google earth elevational profiles, and stereographic projection are the main techniques that used in this research.

The Arkoma Basin is dominated by numerous east-west trending normal faults, forming the general structure of the basin. Additionally, most of those faults are east-west trending faults, such as the Mulberry and Clarksville faults that were reactivated in compressional stress regimes. However, two north-south trending normal faults were analyzed to the northern part of the Mulberry Fault. Evidence from the Lower Atokan Formation suggested a local lithospheric flexure bending in the northcentral part of the study area. This conclusion is supported by the aerial topography of the area as well as the google earth elevation profiles to compare the surface structure of the area with the subsurface structure.

We suggest that the different rates in displacement and relatively huge curvatures on the fault surfaces of the Mulberry fault zone are responsible of forming local sub-basins in the study area. One of these sub-basins is what we called in this study the Bullfrog sub-basin.

Since the surface structure style of the study area has similar characterizations to the subsurface structure, it is considered to be a reliable source to depend on. Further subsurface studies are needed to have more understanding of the mechanism and stress regimes of faulting in the Arkoma Basin.

\section{Acknowledgements}

Our view of the tectonics of the Arkoma Basin in relation to the subsurface structure benefited from discussions and collaborations with Dr. Mac Gillvery at the University of Arkansas. We thank Ms. Jamie Woolsey for providing the well logs data and for her training in analysis of the well logs. We thank Dr. Leftwitch for reviewing this paper and his valuable ideas. We are also grateful to Dr. Delvaux and Sperner for their Win-Tensor program, and Wessel and Smith for the GMT software.

\section{References}

[1]. McGilvery, T., A., Lithostratigraphy of the Brentwood and Woolsey Members, Bloyd Formation (Type Morrowan) in Washington and Western Madison Counties, Arkansas, Master's Thesis, unpublished, University of Arkansas, Fayetteville, 1982.

[2]. Houseknecht, D.W., 1986, Evolution from passive margin to foreland basin--the Atoka Formation of the Arkoma basin, southcentral U.S.A.: International Association of Sedimentologists Special Publication 8, p. 327-345.

[3]. Houseknecht, D.W., and Kacena, J.A., 1983, Tectonic and Sedimentary Evolution of the Arkoma Foreland Basin, TectonicSedimentary Evolution of the Arkoma Basin and Guidebook to Deltaic Facies, Hartshorne Sandstone, v. 1, p. 3-33.

[4]. Long, W., A., The Mulberry Fault Zone: An Analysis of Subsurface Geometry and Timing of Fault Displacement:, Master's Thesis, unpublished, University of Arkansas, Fayetteville, 2005.

[5]. Collier, A. J., White, D., and Girty, G. H., 1907, The Arkansas coal field (No. 326), Geological Survey (US).

[6]. Al-Asadi, F. T., Initial Structural Subsidence as Reflected in Morrowan and Atokan (Pennsylvanian) Subsurface Stratigraphy, Northern Arkoma Basin, North-Central Arkansas, Master's Thesis, unpublished, University of Arkansas, Fayetteville, 2016.

[7]. Delvaux, D., 1993, The TENSOR program for paleostress reconstruction: examples from the east African and the Baikal rift zones, In: Terra Abstracts. Abstract supplement No. 1 to Terra Nova, 5, 216.

[8]. Delvaux, D. and Sperner, B., 2003, Stress tensor inversion from fault kinematic indicators and focal mechanism data: the TENSOR program, In: New Insights into Structural Interpretation and Modelling (D. Nieuwland Ed.). Geological Society, London, Special Publications, 212: 75-100.

[9]. Delvaux, D. and Barth, A., 2010, African Stress Pattern from formal inversion of focal mechanism data. Implications for rifting dynamics, Tectonophysics 482, 105-128. 